\title{
Commissioning artists: community engagement, ethnographic collections, and changes in curatorial practices from the 1990s to 2000 s in the UK.
}

\section{Dr Nicola Ashmore University of Brighton, UK}

The commissioning of artists, makers and communities to respond to collections is an important curatorial strategy used by many national and regional museums and galleries. The display of commissioned work within the ethnographic collections at Brighton Museum and Art Gallery and Manchester Museum are focused upon in this investigation. They are presented as examples of regional museums in England responding to the authority of the 'New Labour government's' cultural policies. The role these commissioned pieces play is discussed in relation to shifts in curatorial practices; the influence of New Labour's cultural diversity agenda on this activity; the emphasis placed on the visibility of community engagement; and the issues surrounding the framing of these museum commissions as 'authentic'.

\section{Keywords}

Commissioning artists; community engagement; authenticity; ethnographic collections; regional museums; cultural diversity agenda.

Curating can be usefully considered as a process of meaning making that involves a range of people from both inside and outside of the museum and gallery. Here the curatorial practice of commissioning artists as a form of community engagement will be discussed. This particular act of commissioning asks people living in the local area, categorized as ethnic minorities, to participate in their own representation and locates them as a representative of their attributed community. This practice is a noticeable departure from that of artists in the 1990s that could be characterized as providing an institutional critique of the museum. The impact of the commissioning practice upon the artist's level of autonomy will be critically considered through the discussion of four commissions that took place between 1995 and 2009.

\section{Identity politics}

In museums policy and practice in the late twentieth and twenty-first century, an emphasis is frequently placed on ethnicity when describing and categorising people. 'BME' (Black, Minority, Ethnic) is a prevalent acronym, 
alongside the phrase 'ethnic minorities,' and 'culturally diverse,' used to classify people within cultural policies who are not white and who may or may not be British. The possible limitations of cultural diversity are a point of departure for this investigation, which questions whether the 'cultural diversity' agenda shaped by the New Labour government's politics (1997-2010) maintains practices of containment of cultural difference through its manifestation in museum practices and considers how policy is negotiated in practice. Notably definitions of diversity change over time within schemes and can expand to encompass a wide range of elements. Definitions also differ between institutions, individuals and organisations. However the assumption that underpins this practice remains the same, regardless of the author or user, and that is it is acceptable to categorise people in line with a minority status, this notion is paradoxical. Homi Bhabha locates 'cultural diversity' as a product of multiculturalism and indicates the active "containment" of cultural difference through this idea:

[A]lthough there is always an entertainment and encouragement of cultural diversity, there is always also corresponding containment of it. A transparent norm is constituted, a norm given by the host society or dominant culture, which says that 'these other cultures are fine, but we must be able to locate them within our own grid'.?

The emphasis placed on identity-based categories in cultural policies has not gone uncriticised. ${ }^{3}$

A phrase also in use within anthropology and museum studies is 'source communities,' this expands upon the expression 'originating communities.' The term source communities is one of the most recent phrases used to describe people from which objects were colonised. Interestingly it does not privilege ethnicity or colour but instead suggests a relationship with a geographical place which is more important. It is considered a neutral way of describing former colonies. Laura Peers and Alison K. Brown explain that the phrase refers to:

\footnotetext{
${ }^{1}$ Homi Bhabha and Jonathan Rutherford, "Interview with Homi Bhabha, The Third Space," Rutherford 208-209.

${ }^{2}$ Bhabha and Rutherford 208.

${ }^{3}$ For critical discussion on identity based cultural policies see: Sonya Dyer, ed., Research papers: Boxed in, How cultural diversity policies constrict black artists (Newcastle upon Tyne: a-n The Artists Information Company, 2007) print; The Institute of Ideas, "Cultural Diversity: A Straitjacket for the Arts?," Battle of Ideas (London: Institute of Ideas, 2007) 27, print.
} 
Groups in the past when artefacts were collected, as well as to their descendants today [...]. [Incorporating] every cultural group from whom museums have collected: local people, diaspora and immigrant communities, religious groups, settlers, and indigenous peoples. ${ }^{4}$

The relationship between museums and source communities is of particular interest here. Peers and Brown amongst others point out that reports on museum and source community collaborations are limited. ${ }^{5}$ For they:

Have focused on the positive benefits for both partners and have tended to skim over the problems encountered and how they were over come [...]. However, this has led to serious omissions in the literature; methodological, institutional and cross-cultural difficulties have been glossed over, despite the fact that such challenges are inherent in this kind of work. ${ }^{6}$

A reflection upon the limitations of 'cultural diversity' policies and related practices that engage source communities is formed here. ${ }^{7}$ It does so through an analysis of the commissioning of 'source community' artists in two regional museums in England: Brighton Museum \& Art Gallery and Manchester Museum. The focus will be on the installation of this artwork in the galleries, which display the ethnographic collections.

\section{The practice of commissioning artists}

Within museum ethnographic collecting the commissioning of source community artists and makers is a very established practice. Chantal Knowles writing in the Journal of Museum Ethnography, in 2003 highlights:

Commissioning items for collections goes right back to the first collectors: anthropological fieldworkers working within the theory of salvage ethnography, obsessed over collecting 'complete' or

\footnotetext{
${ }^{4}$ Laura Peers and Alison K. Brown, "Introduction," Peers and Brown 2.

${ }^{5}$ See for example the following texts that highlight the lack of critical analysis on museum and source communities collaborative practice, Jo Littler, "Heritage and "Race," Graham and Howard 99; Roshi Naidoo, "Never Mind the Buzzwords," Littler and Naidoo 36.

${ }^{6}$ Peers, Laura and Brown Alison K. "Introduction." Peers and Brown 10.

${ }^{7}$ Texts which do critically reflect upon museum and source communities working practice include, James Clifford, Routes: Travel and translation in the late twentieth century (Cambridge: Harvard University Press, 1997) print; C. Dunstan, "Fostering symbiosis: a collaborative exhibit at the California State University Sacramento Museum of Anthropology," Museum Anthropology, 22 (3) (1999): 52-58, print; C. Kreps, "Museum-making and indigenous curation in Central Kalimantan, Indonesia," Museum Anthropology, 22 (1) (1998) 5-17, print.
} 
'representative' collections were frequent commissioners of items. The artefacts they procured may have been made in order to replicate an artefact that was already obsolete, or to acquire a 'pristine' or unused version of something they had seen, or even to obtain scale models of large items that they could not hope to ship home. ${ }^{\prime 8}$

This may usefully be considered as the legacy of the contemporary commissioning of source community artists, from local artists to well-known conceptualists such as Fred Wilson. Within contemporary ethnographic exhibitions nineteenth-century collecting practices, in which makers are commissioned to complete collections, are often juxtaposed with late twentieth-century notions of presenting cultural diversity. As a consequence of either practice unrepresentative objects or activities can occur that do not reflect a culture or a people accurately. Yet authenticity is considered to be at the core of the commissioning practice, manifest in both the output and the process of involvement of source communities. In an article in a 2009 issue of the Museums Journal Felicity Heywood shows the ongoing importance placed on 'authenticity.' She states: 'It is clear that the main benefit to the museum in working with indigenous individuals or groups is to bring authenticity to the collections. ${ }^{\prime 9}$ It seems the very presence of indigenous people in the museum is thought to convey authenticity and credibility, lending kudos to the collections and the museum. Interestingly, the search for authenticity is at once a nineteenth-century mission and a late twentieth- and twenty-first century preoccupation.

\section{Art commission as 'contact zone'}

The artwork commissioned can be more accurately considered to function as a 'contact zone.' Mary Louise Pratt articulates the complexities of the colonial encounter in terms of a "contact zone" in Imperial Eyes: Travel Writing and Transculturation. ${ }^{10}$ Pratt's analysis enables a repositioning of the colonial encounter in terms of a cross-cultural, two-way relationship, whilst acknowledging implicit power imbalances. ${ }^{11}$ James Clifford in Routes: Travel and Translation in the Late Twentieth Century also "borrows"12 Pratt's notion

\footnotetext{
${ }^{8}$ Chantel Knowles "Commissioning Art: Objects, Ethnography and Contemporary Collecting" Journal of Ethnography, No 15 (2003): 57.

${ }^{9}$ Felicity Heywood "Source materials" Museums Journal Vol 109, No 2 (2009): 27.

${ }^{10}$ Mary Louise Pratt, Imperial Eyes: Travel Writing and Transculturation (London: Routledge, 1992) 6-7, print.

${ }^{11}$ Pratt 7.

${ }^{12}$ Clifford, Routes 192.
} 
of the 'contact zone'. He applies it to late $20^{\text {th }}$ century museums and the relationship between the museum and what, for Pratt, is the colonised, that is, those currently referred to as source communities. Clifford uses the terms "contact history" and "contact relations" to describe an ongoing complex and contentious relationship, with a past and a present, between source communities and the "collecting museum."13

In museums, concern with the representation of ethnicity in redisplay did not begin in 1997 or with New Labour but with a longer history of development of postcolonial curatorial strategies. ${ }^{14}$ However, further adding to the 'contact history' and 'contact relations' of commissioned artwork, in this period, is an important convergence between the museum sector's 'cultural diversity' policies, informed by New Labour's identity based cultural policies and community cohesion agenda, with museum ethnographers' existing work with communities influenced by the call for self representation. This convergence could be seen in what Christina Kreps refers to as a concern "with people's living cultures and not just their past." ${ }^{\text {15 }}$ This concern is evident within the case studies that have been selected for close analysis. And in this context the contact is almost recast as a therapeutic process.

\section{The changing role of artists in the museum context}

The focus will now be on four artist commissions. Evident in these case studies are significant changes in commissioning practices that have impacted upon the role artists' play in regional museums. This period covers the duration of the New Labour government's administration, from 1997 to 2010.

The artists involved can be characterized as taking on different roles influenced by the act of commissioning itself, these include: artist as critic in 1995 in Peep at Brighton Museum; artist as maker in 2002 in Hindu Shrine Project at Brighton Museum; artist as facilitator in 2003 in Rekindle at Manchester Museum; culminating in 2009 in Your Museum, Your Stories

\footnotetext{
${ }^{13}$ Clifford, Routes 193.

${ }^{14}$ For example, in 1986 the annual conference of the Museum Ethnographers Group at Bristol Museum and Art Gallery discussed the importance of multiculturalism, this is noted in, Annie E. Coombes, "Ethnography and the formation of national and cultural identities," The Myth of Primitivism, ed. Susan Hiller (London: Routledge, 1991) 189, print. The meaning of multiculturalism is also discussed in relation to museum ethnographic exhibitions in, Annie $\mathrm{E}$. Coombes, "Inventing the 'Postcolonial': Hybridity and Constituency in Contemporary Curating," New Formations, No. 18 (1992) 44, print.

${ }^{15}$ Christina Kreps, Liberating Culture (London: Routledge, 2003) 149, print.
} 
when the identity of the artist has gone and they appear as a museum collaborator.

\section{Artist as critic}

Artists have effectively emphasized the ways in which galleries and museums function as political institutions. Consequently the neutrality of the 'white cube' and the 'ethnographic exhibition' was actively contested from the late 1960s throughout the 1970s and 1980s. As Jennifer A. Gonzalez states, contemporary artists provided "a critical, activist role in drawing attention to museums as institutions that produce ideologies of cultural containment, cultural hierarchy, and cultural legitimacy."16 This body of work often challenged its visitors and encouraged them to question their own understanding of museums and galleries.

In 1968 Eduardo Favario's Closed Gallery Piece presented the gallery as an abandoned space and required visitors to actively seek out the artwork in another part of the city. This transformed the visitors' involvement with the artwork and forced them to give up their state of "static contemplation."17

Notably Hans Haacke is an artist who has repeatedly encouraged visitors to reflect upon museums involvement with corporations. Travis English highlights that Haacke's work demonstrates that "this relationship between museums and their corporate sponsors is one of exchange and not simply one of patronage." ${ }^{\prime 18}$ This relationship is notably shown in, On Social Grease (1975) and Metro Mobiltan (1985) both of which demonstrate how oil money is funding modern art.

James Luna in 1987 created The Artifact Piece in which he displayed himself and some of his belongings as 'artifacts' in the San Diego Museum of Man, in the Kumeyaay Indians section. ${ }^{19}$ Jennifer Gonzalez states:

Lying in a display case, covered with a deerskin loincloth as if frozen in time, Luna enacted the ideological effect museums have upon living

\footnotetext{
${ }^{16}$ Jennifer A. Gonzalez, Subject to Display: Reframing Race in Contemporary Installation Art (Cambridge: The Massachusetts Institute of Technology Press, 2008) 66, print.

${ }^{17}$ Eduardo Favario, "Project for the Experimental Art Series (1968)," Institutional Critique, eds. Alexander Alberro and Blake Stimson (London: The MIT Press, 2009) 72, print.

${ }^{18}$ Travis English "Hans Haacke, or the Museum as Degenerate Utopia" in Kritikos, an international and interdisciplinary journal of postmodern cultural sound, text and image, Vol. 4, March 2007. Web. 7. Jul. 2012.

19 Jennifer A. Gonzalez, Subject to Display, 14.
} 
populations when they present indigenous peoples (such as his own Luiseno tribe) as already extinct. ${ }^{20}$

This influential artwork has moved subsequent artists to interrogate the paradoxical relationship between living cultures and the museum with its colonial legacy.

Fred Wilson's seminal exhibition Mining the Museum (1992) at the Maryland Historical Museum recast the entire museum as a place with a distinct point of view. A point of view that systematically ignored the local areas agricultural, economic and historical past that was intertwined with slavery. Time periods were included in the display label titles throughout the exhibition, for example Modes of Transport 1770-1910. The periodisation acknowledges key dates and events in an African-American history that was largely absent in the Museum.

Sonia Boyce's Peep is part of this tradition of institutional critique. Peep was one of three temporary exhibitions that took place in 1995 at Brighton Museum that worked with the ethnographic collections. ${ }^{21}$ Then Keeper of Ethnography, Anthony Shelton actively integrated artists into a department wide reflection upon the role and practices of museums, to stimulate debate on the politics of display.

Through the first half of the 1990s Anthony Shelton, Keeper of Ethnography at Brighton Museum and Lecturer in non-Western art and critical museography, ${ }^{22}$ actively shows commitment to the idea of the museum as an important site to encourage debate. In the article "Constructing the global village", published in 1992, he, proposes that museums should "re-define themselves as facilitators whose custody of space and meaning is loosened to enable new relationships with indigenous representatives, minorities, artists and academics to be constructed."23

The temporary exhibitions, Shelton commissioned, that involved artists in 1995 were titled Hold, 11 March - 2 April 1995, Fetishism: Visualising Power

\footnotetext{
${ }^{20}$ Jennifer A. Gonzalez, Subject to Display, 15.

${ }^{21}$ S. Boyce; Royal Pavilion, Art Gallery and Museums, Brighton; Institute of International Visual Arts; Green Centre for Non Western Art and Culture, Peep (London: Institute of International Visual Arts, 1995).

${ }^{22}$ Anthony Shelton was a lecturer at this time at Sussex University and East Anglia University.

${ }^{23}$ Shelton, "Constructing the global village" 26.
} 
and Desire, 29 April - 2 July 1995; and Peep, 29 April - 1 August 1995. All three exhibitions actively encouraged visitors to think about museum practices of making meaning, this will be explored next.

Shelton co-organized Peep along with the Institute of International Visual Arts, also known as INIVA. This process of collaboration between a museum, an arts institution and an artist is a practice that is still common today. ${ }^{24}$

In Peep, Sonia Boyce created a series of installation artworks for one of the ethnographic galleries at Brighton Museum titled the Cultures Gallery. ${ }^{25}$ Shelton cites Boyce's artistic intervention in his article "The future of museum ethnography" 26 as evidence that and I quote "museum ethnography can no longer avoid an engagement, which is long overdue and which is a necessary overture to rethinking the politics of its own display practices." ${ }^{27}$ Gilane Tawadros, co-organiser of Peep, supports this notion through her description of the intervention:

The transparent glass display cases, which usually present artefacts and objects from around the world have been hidden from view behind opaque paper sheeting. To see the objects now, you are forced to move up close to the glass cases and peer through the uneven shapes cut out of the tracing paper. Looking through these strangely shaped openings, your view is limited, partial and incomplete and you are made to feel self-conscious about the act of looking, as if the artist was determined to make us peeping toms. But perhaps that is what museums are all about. ${ }^{28}$

Boyce's work is clearly in line with this critical period in the ethnographic department at Brighton Museum, to engage in the politics of display. For Boyce's artwork brings into question the practice of looking, implicit in the museum experience, the process is exaggerated, encouraging visitors to think about the meaning of their involvement. The view presented to visitors of the

\footnotetext{
${ }^{24}$ See Ken Arnold, the head of public programmes at the Wellcome Collection interviewed in, Simon Stephens, “Artistic merit,” Museums Journal, Vol 112, No 5, May (2012): 27.

${ }^{25}$ Sonya Boyce and Anthony Shelton refer to the permanent ethnographic gallery as the Cultures Gallery, in the catalogue that accompanied the exhibition "Peep." See Peep (Brighton: Institute of International Visual Arts and the Green Centre for Non-Western Art and Culture at the Royal Pavilion, Art Gallery and Museums: 1995).

${ }^{26}$ Anthony, Alan, Shelton, "The Future of Museum Ethnography" Journal of Museum Ethnography, No 9 (1997): 43-44.

27 Shelton, "The Future of Museum Ethnography" 44.

${ }^{28}$ Gilane Tawadros, "Peeping Toms," in Peep: 3.
} 
objects in the cases is also highlighted, which in turn illuminates the practice of constructing a point of view, revealing the contrived nature of the museum display.

Within this act of commissioning it seems there was a clear expectation for Boyce to take on the role as 'artist as critic' in which she was encouraged to provide an institutional critique. Interestingly no overt emphasis is placed on the artist's ethnicity. For instance, neither Shelton nor Tawadros from the coorganizing institutions refer to Boyce's Guyanian diasporic status in the associated exhibition publication. The focus is firmly on her artistic and conceptual contribution to the Museum site. A noticeable departure from this type of integration of artists into critical museum practice occurs a few years later at Brighton Museum. And indicative of sector wide changes the ethnicity of artists becomes more important and visible in the twenty-first century.

\section{The influence of policy and funding on commissioning practices}

By 2002 the year of the next Brighton Museum case study, artistic interventions have been largely reshaped and altered through commissioning practices, to promote cultural diversity. Art commissions involving source communities, displayed in permanent ethnographic galleries, are used to demonstrate the museum's commitment to the promotion of diversity to funders, visitors and source communities themselves. The output of the art commission is increasingly valued for showing source communities input. This reflects a current preoccupation in collecting practice with living cultures, which like $19^{\text {th }}$ century practices shows a preoccupation with authenticity. Through the installation of these art commissions into the permanent galleries the Museums are able to make visible local communities access to collections. In line with cultural diversity policies and practices visibility of community engagement is an increasingly important consideration for museums.

The idea of an inclusive multicultural society was promoted by New Labour as a visioning of Britain that has located cultural policies as 'duties' created for the benefit of Britain. Cultural policies are over arching and museum policies are a particular variant, but it is the variant where cultural diversity has come into play significantly pertaining to access, diversity, identity, and community cohesion. The museum priorities detailed in the report Understanding the Future: Priorities for England's Museums is a particular formulation of these cultural policies. This document created by the Department for Culture, Media and Sport, published in October 2006, details the Government's priorities for museums in England for the next ten years. It can usefully be considered as 
the culmination of nine years of policy activity, between 1997 and 2006, which has endeavored to articulate the role of museums in this period of New Labour administration. Within this 2006 report five priorities are laid out for England's Museums with a number of objectives stipulated for each. The priorities are detailed below; numbers two, three and four are of particular interest and embed in the role of the museum, practices of cultural diversity through community engagement, collecting and staffing:

1. Museums will fulfil their potential as learning resources $[\ldots]$.

2. Museums will embrace their role in fostering, exploring, celebrating and questioning the identities of diverse communities [...].

3. Museums' collections will be more dynamic and better used [...].

4. Museums' workforces will be dynamic, highly skilled and representative [...].

5. Museums will work more closely with each other and partners outside the sector. ${ }^{29}$

In the second priority it is made clear that a key focus of the museum is to actively support and develop the "identities of diverse communities" through community engagement. ${ }^{30}$ Museums' community engagement work is a key subject discussed in this essay through the case study institutions' artist commissions. The third priority addresses museums' collecting activity and notably in objective 3.f. the focus is placed on the importance of collecting "contemporary society." The practices that have evolved around the collection of living cultures are an important theme investigated in the three remaining artist commissions to be discussed. The fourth priority relates to museum staffing and the importance of the workforce to be "representative;" this is stipulated specifically in 4. h. "Museums' governing bodies and workforces will be representative of the communities they serve." ${ }^{31}$ The steps made by the case study museums to be representative will be explored, starting with the Hindu Shrine project at Brighton Museum.

\section{Commissioning artists: contact relations and the claim of authenticity}

Authenticity, as discussed, is associated with the commissioning process. The visible involvement of source communities to add to the interpretation of

\footnotetext{
${ }^{29}$ DCMS, Understanding the Future: Priorities for England's Museums (London: DCMS, 2006) 27-28, PDF file.

${ }^{30}$ DCMS, Understanding the Future 27.

${ }^{31}$ DCMS, Understanding the Future 27.
} 
existing collections, to create objects or to have a physical presence in the museum is thought to transmit authenticity and integrity. Yet in the translation of 'cultural diversity' policies into museum practices that call for community engagement and collecting living cultures ${ }^{32}$ complex contact relations are at play. James Clifford importantly frames the museum within this intricate context, using the idea of the contact zone. He states: "When museums are seen as contact zones, their organizing structure as a collection becomes an ongoing historical, political, moral relationship - a power-charged set of exchanges, of push and pull." ${ }^{33}$ Clearly politics, morality and power are at play within the museum, pertinently so within the context of the ethnographic gallery space in which colonial collections are present ${ }^{34}$. The relationship between the museum and the commissioned artist is not an equal one. The parameters of the engagement are predetermined by the museum from the start and yet still the air of authenticity persists. Clifford in The Predicament of Culture goes as far as describing the museum as a "machine for making authenticity," ${ }^{35}$ an authoritative institution that manufactures legitimacy.

The next case study highlights the control of the museum over the identities of the artist commissioned and the people engaged, undermining its inclusive intentions.

The Hindu Shrine Project was on permanent display in Brighton Museum's ethnographic gallery for nine years between 2002 and 2011. The artist Balavendra Elias was commissioned to work in consultation with people living in Brighton from the Hindu community to carve three domes to go on top of an existing 19th century shrine held in the collection and a donation box. People from the Brighton \& Hove Hindu Women's Group and Hindu Elders' Group made garlands, jewellery and clothes for the deities and also dressed the shrine, and contributed to a booklet on Hinduism, all of which were placed on permanent display. ${ }^{36}$ The Museum had already commissioned Balavendra Elias in 1997 to carve a statue of Ganesh for the 1997 exhibition: India in Brighton. The Ganesh statue was also on permanent display from 2002. The accompanying "Ganesh" label makes reference to the 1997 exhibition, which

\footnotetext{
${ }^{32}$ DCMS, Understanding the Future.

${ }^{33}$ Italicised words Clifford's emphasis; Clifford, Routes 192.

${ }^{34}$ For further discussion on the power at play within museums with ethnographic collections see Sally Price, Primitive Art in Civilized Places (Chicago: The University of Chicago Press, 1989).

${ }^{35}$ James Clifford, The Predicament of Culture: Twentieth-Century Ethnography, Literature and Art (Cambridge, MA: Harvard University Press, 1988) 224.

${ }^{36}$ Toni Parker, "A Hindu Shrine at Brighton Museum” Journal of Museum Ethnography, No. 16 (2004): 65.
} 
displays the longevity of the contact relationship between the Museum and the local Hindu community. The label identifies Balavendra Elias not as an artist but as the maker stating: "Made by Balavendra Elias." This label follows the house style (see Figure 1), it is unusual though within the gallery because the maker is known; the majority of the object labels state: "Maker unrecorded." The title of 'maker' clearly has ethnographic value within this context. The first section of the gallery was titled 'Makers' and the accompanying text panel formed a tribute to all the makers whose names were not recorded by collectors. The naming of a maker within the context of this gallery is significant and could be interpreted as a gesture in the present to address some of the wrongs of the past. However, counter to this, a curatorial decision was made to not label the items on the Hindu shrine made by a number of different people "as it was felt that this would detract from the visual and spiritual impact of the shrine. ${ }^{137}$ Misleadingly only one person, Mrs Mohini Bansai, was acknowledged for making the silk decorations and costumes for the deities and this is recorded in the back of the booklet that accompanied the exhibit titled: Hinduism in Brighton. The text panel that did accompany the shrine identified two groups as contributors; promoting the group identity and not acknowledging individual makers. The panel also implies the authentic nature of the display stating that the shrine: "has been dressed by members of the Hindu Women's Group and Hindu Elders' Group." Yet conservation practices at the museum inhibited the traditional repairing of the peeling paint on the $19^{\text {th }}$ century shrine or painting of the bare wood of the Ganesh statue, the domes on top of the shrine (see Figure 2), or the donation box. This was an issue of real contention between the Museum and the groups but this compromise was not communicated in the display or in the accompanying literature, actively silencing these important dialogues for the visitor.

\section{Commissioning artists: recognition and representation}

The third and fourth case studies attend to commissioning practices at Manchester Museum. Including the type of voice given to the source communities engaged and the changing role of the artist, from a facilitating named artist to a museum collaborator represented as an unnamed voice of authority.

The Rekindle series is displayed in the 'Living Cultures' gallery in Manchester Museum, in place since 2003. Located in between cases found throughout the gallery are a number of audio-visual stations (see Figure 3). The commissioned artist was Kuljit Chuhan a local digital media artist, Chuhan

${ }^{37}$ Parker, "A Hindu Shrine at Brighton Museum" 65. 
created a total of eighteen videos depicting two poets and members of the recently created Manchester Museum's Community Advisory Panel speaking to objects from the ethnology collection. The Community Advisory Panel consists of people living within a six mile radius of the museum. The area surrounding the Museum is considered to be one of the city's most diverse and therefore suitably representative, in line with 'cultural diversity' policies. ${ }^{38}$ Chuhan came up with the idea of asking the participants to speak to the objects facilitating a connection between people from the local area with the Museum's collections. There is a sense of a dialogue between the past (the collection) and the present (the participants), which can also be read as a statement by the Museum about progress, from colonialism to outreach and inclusion, source communities being given a voice. The videos function as a series of signs and indicate the community at large, actively showing their inclusion and representation. Bernadette Lynch who came up with the idea for Rekindle summarized the intention for the project:

The idea was to encourage others to feel that you don't have to have prior knowledge of an object to respond to an object. We didn't have any control of what was selected or what was said and what was very interesting about that project was how often people chose objects outside of their own cultural heritage. ${ }^{39}$

Because participants predominantly chose objects 'outside of their own cultural heritage' ${ }^{40}$ lived experience of the objects was largely absent in the Rekindle interpretations. This indicates that the value of the spoken interpretations was not considered in relation to ethnographic value or lived experience but lay in the legitimacy of the emotive, imaginative individual engagement with the object. Local people from source communities participating in Rekindle are notably named in the respective exhibits this is juxtaposed with the prevalent institutional voice that runs throughout the gallery, which remains un-named. The interpretations contributed by the participants can be characterised as providing an emotional response that revolves around personal memories, whilst the institution presents the 'facts'.

Another video project titled Collective Conversations developed from the Rekindle series; this will be the focus of the final case study. ${ }^{41}$ From 2009 the Collective Conversations project has been shown in the Your Museum, Your

\footnotetext{
${ }^{38}$ DCMS, Understanding the Future.

${ }^{39}$ Bernadette Lynch, Personal interview (14 March 2005).

${ }^{40}$ Lynch, Personal interview.

${ }^{41}$ Lynch, Personal interview
} 
Stories audio-visual display in the Living Cultures gallery in Manchester Museum (see Figure 4). This video series features members of source communities interacting with objects but in contrast to Rekindle, all of the community participants interact with objects from collections they share a cultural heritage with.

Kuljit Chuhan, the digital media artist who created Rekindle worked closely with the Museum on creating Collective Conversations, developing the process, providing technical expertise and training Museum staff. Chuhan features as a museum collaborator in one of the six Collective Conversations on display titled 'About the history of Benin'. ${ }^{42} \mathrm{He}$ brings the objects to be discussed into shot; he handles them first, and presents them to the three participants, asking questions to prompt dialogue. He is not identified as an artist or even named within the display. Interestingly in the Your Museum, Your Stories display terminal the Collective Conversations are listed detailing the object being discussed but only the source community participant's are named. The curators involved in four of the videos and Kuljit Chuhan the artist collaborator present in another of the films, in contrast are not named. And yet for Collective Conversations to function as a dialogue it is critical that all of the people involved are acknowledged. The absence of the names of the Museum representatives in the context of the ethnographic gallery perpetuates the notion that the Museum is the un-named authority. This omission actively ignores the contact histories and contact relations of the museum, as collector and collection, with the members of the source communities as collected.

The artist Chuhan, through Rekindle and Collective Conversations, has facilitated the Museum and collaborated with the Museum to locate the community presence in the Museum, creating an audio-visual form of intervention. Importantly, in the 2003 redisplay, in Rekindle, Chuhan is clearly identified as an artist in each of the video titles, in 2009 he is presented as a Manchester Museum representative, a museum collaborator in the Collective Conversation he features in ${ }^{43}$ his independence is eroded. By 2009 the artist is firmly absorbed into the Museum's processes to the extent that he now publically represents the Museum, presented as an un-named voice of authority. A significant shift in the context of the ethnographic exhibition from named to un-named.

\footnotetext{
42 "Your Museum, Your Stories," in Living Cultures (Manchester Museum, University of Manchester): touch screen.

${ }^{43}$ The Collective Conversation Kuljit Chuhan features in, is titled: About the history of Benin, see "Your Museum, Your Stories," touch screen.
} 
The collection of interpretations from source communities or living cultures has escalated throughout this period. Collecting interpretations is a collecting practice. It is, however, not often analysed yet in this way. This 'collecting' activity reflects the convergence of policy aims to increase engagement of people categorized as ethnic minorities, with museums' work with source communities, informed by postcolonial debates surrounding the control and production of cultural identities. This convergence, combined with funding prerequisites means the ability to demonstrate access and engagement with people from source communities has become of paramount importance to the museum, which in turn has directly impacted upon curatorial strategies. This paper begins to attend to the impact of these influences on curatorial practices highlighting the erosion of the autonomy of the source community artist through the commissioning process in this period. 


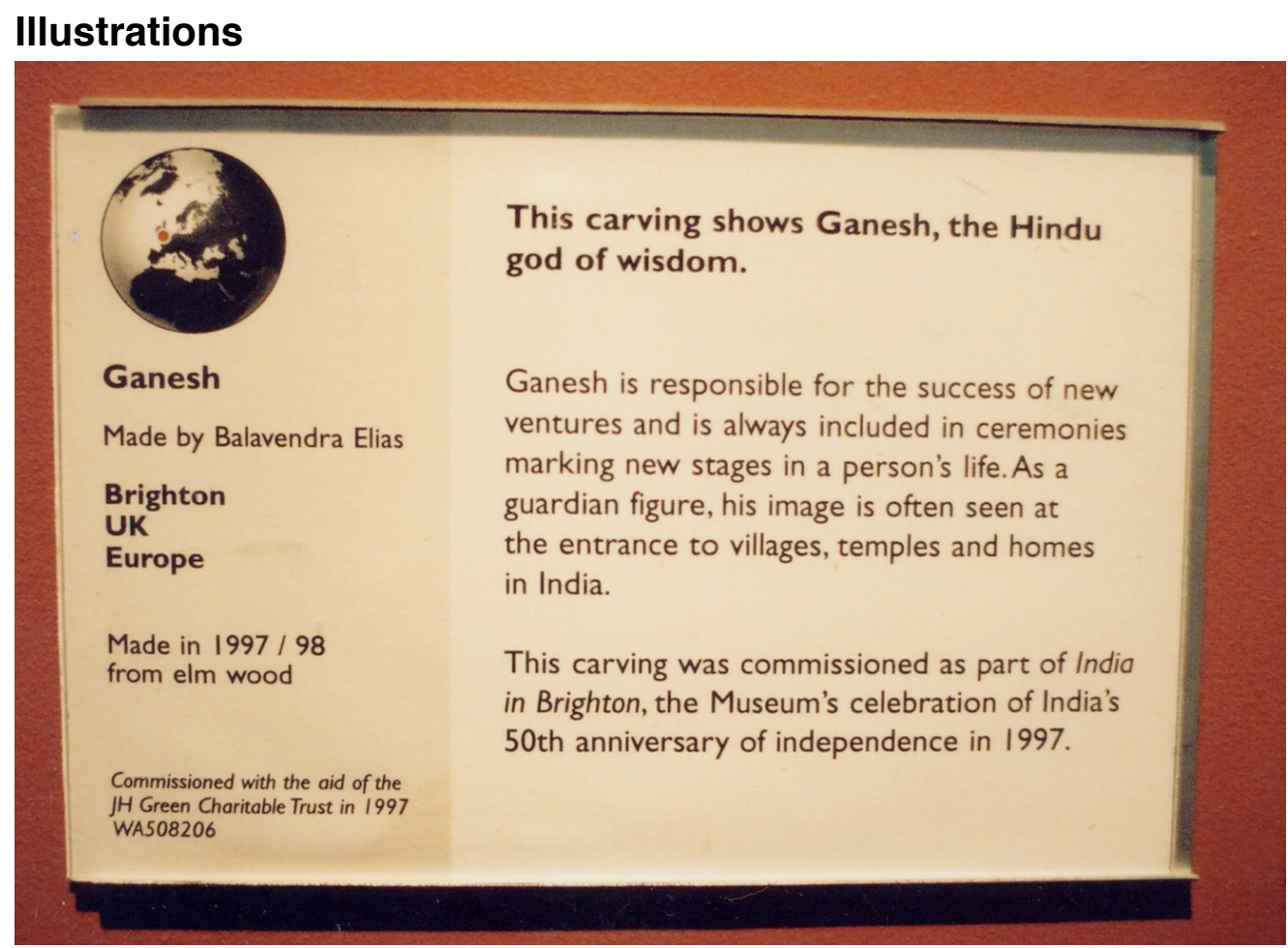

Figure 1. This label for the Ganesh statue clearly states the name of the maker. "Ganesh" object label. The James Green Gallery of World Art. Exhibition. Personal Photograph. 23 Jun. 2006. Copyright Nicola Ashmore.

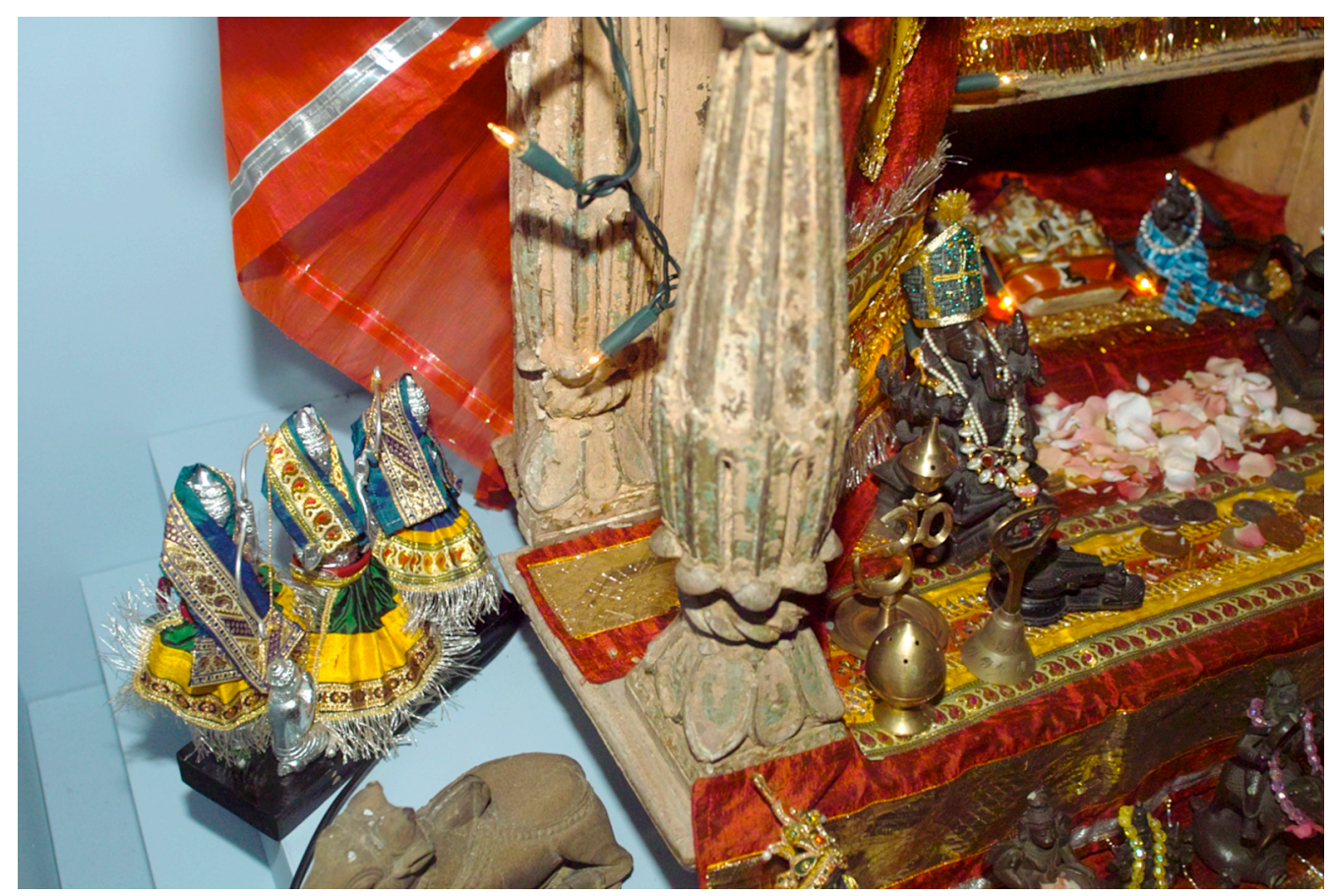

Figure 2. Deities in hand-crafted outfits made by the local Gujarati community as part of the Hindu Shrine Project. The $19^{\text {th }}$ century shrine has been left unpainted adhering to the Museum's conservation practices and not traditional Hindu practices. The James Green Gallery of World Art. Exhibition. Personal photograph. 9 Apr. 2010. Copyright Nicola Ashmore. 


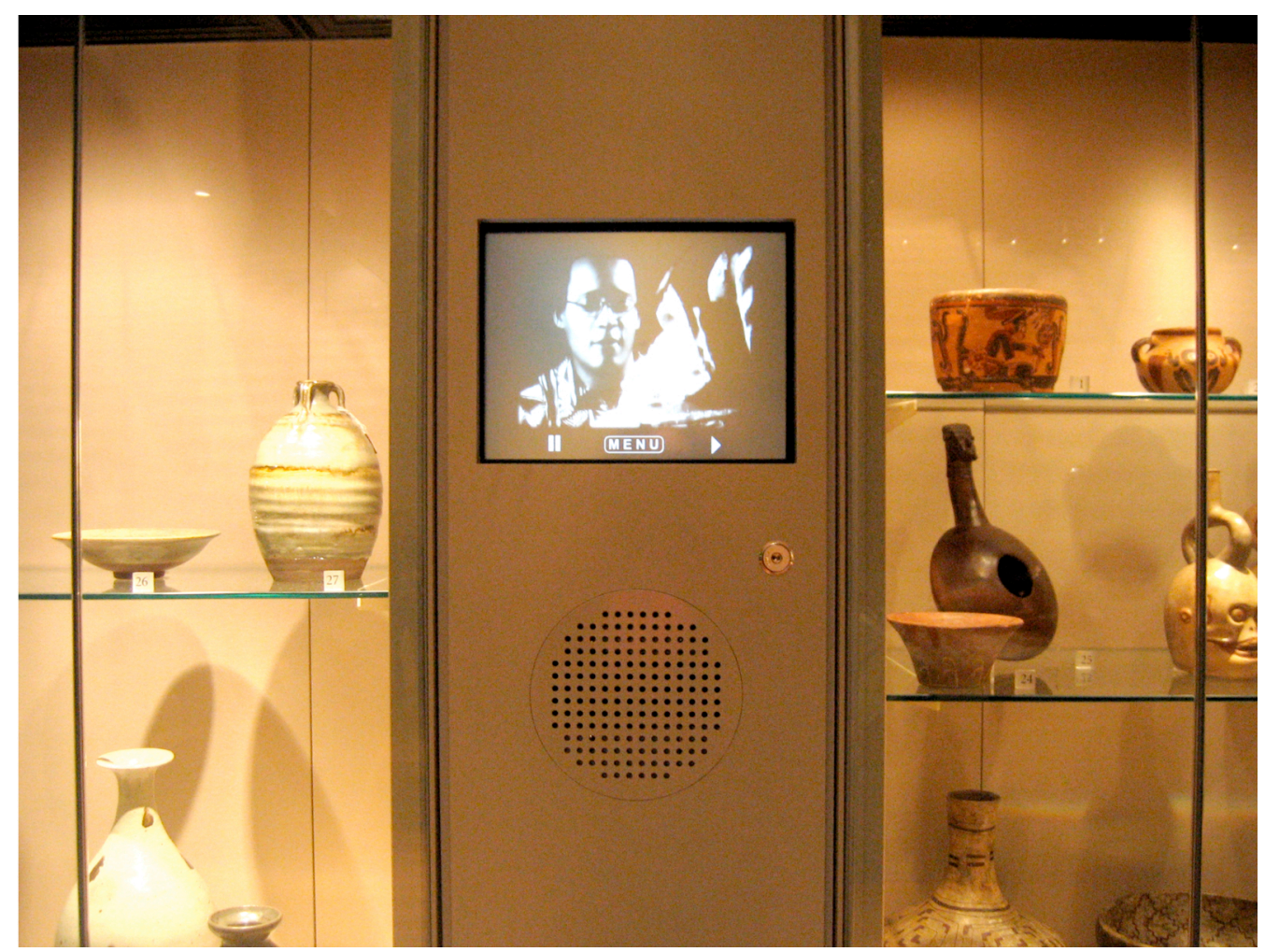

Figure 3. Rekindle screen to the right of the central "Out of Clay" case. Living Cultures. Exhibition. Personal photograph. 12 Mar. 2005. Copyright Nicola Ashmore.

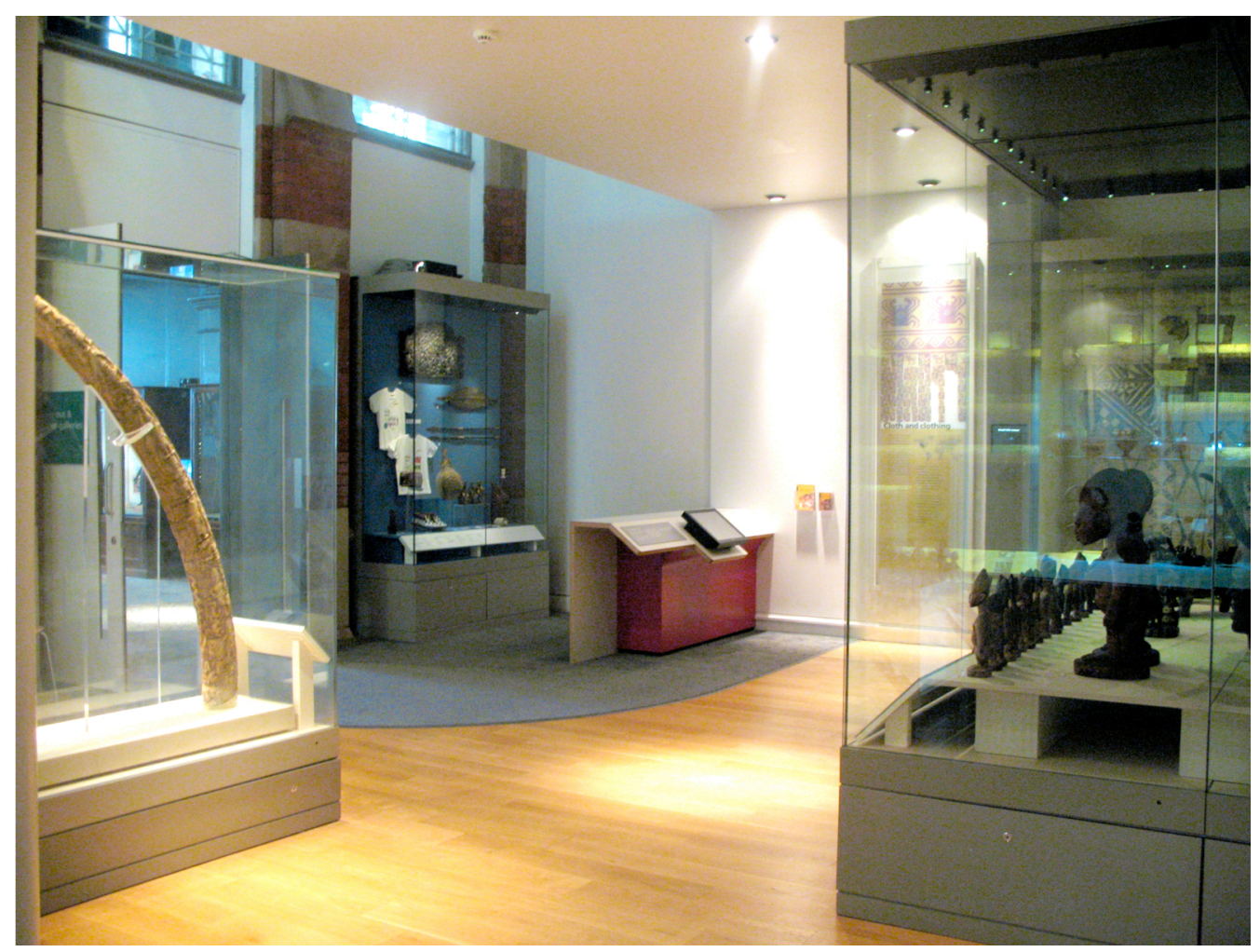

Figure 4. Your Museum, Your Stories exhibit was installed in 2009 in the Living Cultures exhibition. The first of the Living Cultures exhibitions, previously referred to as Explorers and 
Encounters, was replaced in 2009 with The Manchester Gallery. Living Cultures. Exhibition. Personal photograph. 7 Jul. 2010. Copyright Nicola Ashmore.

\section{Bibliography}

Boyce, Sonya. Peep. Brighton Museum and Art Gallery. Brighton. 1995. Exhibition.

Bhabha, Homi and Jonathan Rutherford. "Interview with Homi Bhabha, The Third Space." Rutherford 208-209.

Chubb, Shirley. Hold. Brighton Museum and Art Gallery. Brighton. 1995. Exhibition.

Coombes, Annie E. "Ethnography and the formation of national and cultural identities." The Myth of Primitivism, ed. Susan Hiller (London: Routledge, 1991) 189-214. Print.

---. "Inventing the 'Postcolonial': Hybridity and Constituency in Contemporary Curating." New Formations. No. 18 (1992): 39-52. Print.

Clifford, James. Routes: Travel and translation in the late twentieth century. Cambridge: Harvard University Press, 1997. Print.

---. The Predicament of Culture: Twentieth-Century Ethnography, Literature and Art. Cambridge, MA: Harvard University Press, 1988. Print.

Dunstan, C. "Fostering symbiosis: a collaborative exhibit at the California State University Sacramento Museum of Anthropology." Museum Anthropology. 22 (3) (1999): 52-58. Print.

Dyer, Sonya, ed. Research papers: Boxed in, How cultural diversity policies constrict black artists. Newcastle upon Tyne: a-n The Artists Information Company, 2007. Print.

English, Travis. "Hans Haacke, or the Museum as Degenerate Utopia" in Kritikos, an international and interdisciplinary journal of postmodern cultural sound, text and image, Vol. 4, March 2007. Web. 7. Jul. 2012.

Favario, Eduardo "Project for the Experimental Art Series (1968)," Institutional Critique, eds. Alexander Alberro and Blake Stimson. London: The MIT Press, 2009. 72-74. Print.

Fetishism. Brighton Museum and Art Gallery. Brighton. 1995. Exhibition.

Graham, Brian and Peter Howard eds. Heritage and Identity. Aldershot: Ashgate, 2008. Print.

Gonzalez, Jennifer A. Subject to Display: Reframing Race in Contemporary Installation Art. Cambridge: The Massachusetts Institute of Technology Press, 2008. Print.

Great Britain. DCMS. Understanding the Future: Priorities for England's Museums. London: DCMS, 2006. PDF file. 
Harris, Lisa. Personal interview. 10 Mar. 2005.

---. Personal interview. 5 Mar. 2005.

Heywood, Felicity. "Source materials." Museums Journal. Vol 109 No 2 (2009): 23-27. Print.

Knowles, Chantal. "Commissioning Art: Objects, Ethnography and Contemporary Collecting." Journal of Museum Ethnography. No 15 (2003): 57-66. Print.

Kreps, Christina. Liberating Culture. London: Routledge, 2003. Print.

---. "Museum-making and indigenous curation in Central Kalimantan, Indonesia." Museum Anthropology. 22 (1) (1998): 5-17. Print.

Littler, Jo. "Heritage and 'Race." Graham and Howard 89-104.

Littler, Jo and Roshi Naidoo eds. The Politics of Heritage: The

Legacies of Race. London: Routledge, 2005. Print.

Living Cultures. The Manchester Museum, University of Manchester.

Manchester. 2003-. Exhibition.

Lynch, Bernadette. Personal interview. 14 Mar. 2005.

Naidoo, Roshi. "Never Mind the Buzzwords." Littler and Naidoo 36-48.

"National Association for the Advancement of Colored People

(NAACP)." The Hutchinson Dictionary of World History. Ed. Jennifer Speake. Oxford: Helicon Publishing Ltd, 1993. Print.

Parker, Toni. "A Hindu Shrine at Brighton Museum." Journal of Museum Ethnography. No. 16. (2004): 64-68. Print.

Peep. Brighton: Institute of International Visual Arts and The Green Centre for Non-Western Art and Culture at the Royal Pavilion, art Gallery and Museums, 1995. Print.

Peers, Laura and Brown Alison K. "Introduction." Peers \& Brown 1-16.

---. Eds. Museums and Source Communities. London: Routledge, 2003. Print.

Pratt, Mary Louise. Imperial Eyes: Travel Writing and Transculturation. London: Routledge, 1992. Print.

Price, Sally. Primitive Art in Civilized Places. Chicago: The University of Chicago Press, 1989. Print.

Quarrels, Benjamin. The Negro in the American Revolution.

Williamsburg: University of North Carolina Press, 1961. Print.

Rutherford, Jonathan ed. Identity: Community, Culture, Difference.

London: Lawrence \& Wishart Ltd, 1990. Print.

Shelton, Anthony Alan. "Constructing the Global Village." Museums Journal. Vol. 92, No. 8. (1992): 25-28. Print.

---.ed. Fetishism: Visualising Power and Desire. London: The South Bank Centre, The Royal Pavilion, Art Gallery and Museums in association with Lund Humphries Publishers, 1995. Print. 
---."The Future of Museum Ethnography." Journal of Museum Ethnography. No 9. (1997): 43-44. Print.

Stephens, Simon. "Artistic merit." Museums Journal. Vol 112, No 5. May (2012): 23-27. Print.

The Cultures Gallery. Brighton Museum and Art Gallery. Brighton. 1994-2002. Exhibition.

The James Green Gallery of World Art. Brighton Museum and Art Gallery. Brighton. 2002-2012. Exhibition.

Welsh, Stephen. Personal interview. 7 July 2010.

Wilson, Fred. Mining the Museum. Maryland Historical Society.

Baltimore. 1992-1993. Exhibition.

---. Rooms with a View: The Struggle Between Culture, Content and the Context of Art. Longwood Arts Gallery. New York. 1987. Exhibition.

Tawadros, Gilane. "Peeping Toms." Peep 3.

The Institute of Ideas. "Cultural Diversity: A Straitjacket for the Arts?." Battle of Ideas. London: Institute of Ideas, 2007. Print.

"Your Museum, Your Stories." In Living Cultures. Manchester Museum, University of Manchester. Text panel.

"Your Museum, Your Stories." In Living Cultures. Manchester Museum, University of Manchester. Touch screen. 